\title{
Selective glucose transformation by titania as a heterogeneous Lewis acid catalyst
}

\author{
Kiyotaka Nakajima ${ }^{1,2}$, Ryouhei Noma ${ }^{1}$, Masaaki Kitano ${ }^{3}$, Michikazu Hara ${ }^{1,4, *}$ \\ ${ }^{1}$ Materials and Structures Laboratory, Tokyo Institute of Technology, Nagatsuta-cho \\ 4259-R3-33, Midori-ku, Yokohama 226-8503, Japan \\ ${ }^{2}$ Japan Science and Technology (JST) agency, PRESTO, 4-1-8 Honcho, Kawaguchi 332-0012, \\ Japan. \\ ${ }^{3}$ Tokodai Institute for Element Strategy, Tokyo Institute of Technology, Nagatsuta-cho \\ 4259-R3-33, Midori-ku, Yokohama 226-8503, Japan. \\ ${ }^{4} J a p a n$ Science and Technology (JST) agency, ALCA, 4-1-8 Honcho, Kawaguchi 332-0012, \\ Japan.
}

\begin{abstract}
The Lewis acidity of phosphate-immobilized anatase $\mathrm{TiO}_{2}\left(\mathrm{H}_{3} \mathrm{PO}_{4} / \mathrm{TiO}_{2}\right)$ has been studied to develop novel environmentally benign reaction systems. Fourier transform infrared (FT-IR) measurements suggested that most Lewis acid sites on bare and $\mathrm{H}_{3} \mathrm{PO}_{4} / \mathrm{TiO}_{2}$ surface function even in water. $\mathrm{H}_{3} \mathrm{PO}_{4} / \mathrm{TiO}_{2}$ exhibits high catalytic performance for selective 5-(hydroxymethyl)furfural (HMF) production from glucose in THF/water (90/10 vol.\%) solution. This is attributed to water-tolerant Lewis acid sites on $\mathrm{H}_{3} \mathrm{PO}_{4} / \mathrm{TiO}_{2}$ that promote step-wise conversion of glucose into HMF. The catalyst was easily recovered from reaction solution by simple decantation or filtration, and can be used repeatedly without significant loss of original activity for subsequent reactions.
\end{abstract}

Keywords: Lewis acid; biomass conversion; glucose; HMF

Corresponding author: prof. Michikazu Hara TEL:+81-45-924-5311, FAX:+81-45-924-5381, Email: mhara@msl.titech.ac.jp 


\section{Introduction}

The effective conversion of glucose, a key component of cellulosic biomass, into HMF is an attractive route to sustainable chemical production [1]. HMF is a versatile and key platform chemical because it can be further converted into various polymers such as polyesters and polyamides, and pharmaceuticals [1,2]. However, the lack of a simple and highly efficient process for HMF production from glucose has been an obstacle to the utilization of HMF, a so-called "sleeping giant" [2]. A proposed reaction mechanism for HMF formation from glucose is shown in Scheme 1, where glucose derived from cellulosic biomass or starch is converted into HMF through isomerization, followed by dehydration in the presence of appropriate catalysts.[2] Zhao and co-workers demonstrated that $\mathrm{CrCl}_{2}$, a soluble homogeneous Lewis acid catalyst, dissolved in an ionic liquid functions as the most efficient catalytic system for the reaction, although the maximum HMF yield in the reaction system is still only in the order of $60 \%$ [3]. While serious problems, such as HMF selectivity, separation of the catalyst and HMF from the ionic liquid, reuse of the catalyst, and handling in practical processes remain for this catalytic system with respect to the effective use of glucose and energy costs, the results of this reaction system suggest that Lewis acids function as effective catalysts for the efficient production of HMF from glucose.

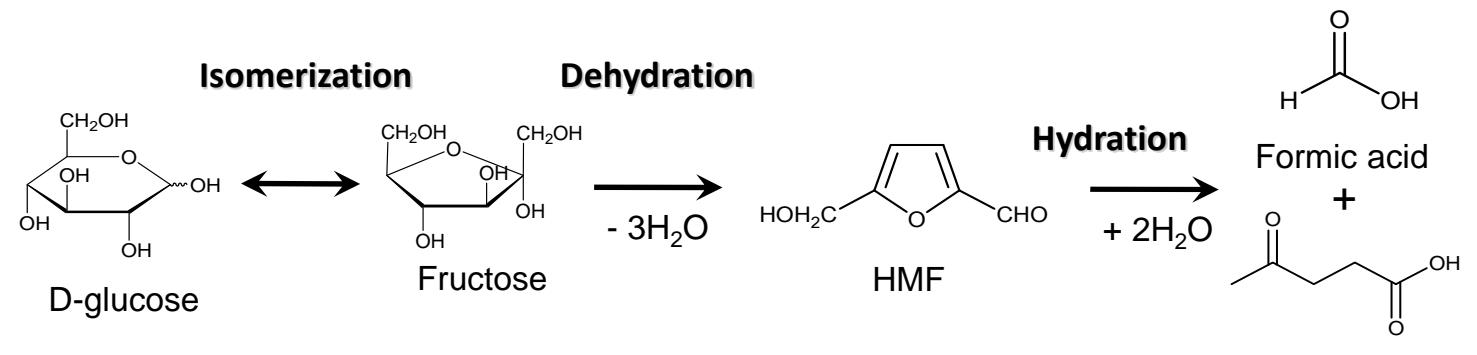

Levulinic acid

Scheme 1. Reaction pathway for acid-catalysed conversion of glucose into HMF in water

Lewis acid catalysts such as $\mathrm{AlCl}_{3}, \mathrm{BF}_{3}$, and transition metal halides are essential for the production of industrially important chemicals, including polymers and pharmaceuticals [4]. However, most Lewis acids decompose or are ineffective in the presence of water, and thereby require dehydrated environment, which results in significant energy consumption. In addition, they have serious drawbacks, such as the production of waste and corrosion of equipment, in addition to requiring separation from the product [5]. Although a few exceptions (rare earth metal triflate complexes [6,7] and $\mathrm{Sn}^{4+}$-incorporated zeolites [8,9]) are known to exhibit Lewis acid catalysis in water, the scarcity of rare earth metals in the former and the narrow reaction space available in the latter limit their utility. Thus, heterogeneous Lewis acid catalysts that are ubiquitous, insoluble, easily separable from products, and highly active for various reactions in water would be applicable to environmentally benign chemical production.

Recently, we reported that a part of $\mathrm{NbO}_{4}$ tetrahedra present in insoluble niobic acid $\left(\mathrm{Nb}_{2} \mathrm{O}_{5} \cdot n \mathrm{H}_{2} \mathrm{O}\right)$ act as Lewis acids even in water [10]. Many metal oxides of groups 4 and 5, including niobic acid, are composed of octahedral $\mathrm{MO}_{6}(\mathrm{M}$ : metal) units with saturated coordination spheres, and polyhedral $\mathrm{MO}_{\mathrm{x}}$ with unsaturated coordination spheres, such as tetrahedral $\mathrm{MO}_{4}$, are also present on the surface. Unsaturated coordination $\mathrm{MO}_{4}$ tetrahedra act as Lewis acids; however, $\mathrm{MO}_{4}$ species are considered to not function as well in water as other Lewis acids. Niobic acid with $\mathrm{NbO}_{4}$ species as water-tolerant Lewis acid sites suggests that anatase $\mathrm{TiO}_{2}$, a ubiquitous material, with $\mathrm{TiO}_{4}$ species on the surface would also function as an insoluble, easily separable, and water-tolerant Lewis acid catalyst. Therefore, the potential of anatase $\mathrm{TiO}_{2}$ as a heterogeneous water-tolerant Lewis acid was investigated in this study. 


\section{Experimental}

\subsection{Preparation of anatase $\mathrm{TiO}_{2}$ and $\mathrm{H}_{3} \mathrm{PO}_{4} / \mathrm{TiO}_{2}$}

Anatase $\mathrm{TiO}_{2}$ was synthesized by the addition of $20 \mathrm{~mL}$ Ti(i-pro) 4 to $100 \mathrm{~mL}$ distilled water, followed by stirring at room temperature. After $6 \mathrm{~h}$, the filtrated white precipitate was stirred in $200 \mathrm{~mL}$ of $1 \mathrm{M} \mathrm{HCl}$ solution for $2 \mathrm{~h}$ to complete the hydrolysis of residual Ti-OCH $\left(\mathrm{CH}_{3}\right)_{2}$ species. The obtained powder was repeatedly washed with distilled water (ca. $1000 \mathrm{~mL}$ ) until the $\mathrm{pH}$ of the filtrate became neutral. The resulting material was dried overnight at $353 \mathrm{~K}$ and then used as the anatase $\mathrm{TiO}_{2}$ catalyst.

$\mathrm{H}_{3} \mathrm{PO}_{4} / \mathrm{TiO}_{2}$ was prepared by immobilizing $\mathrm{H}_{3} \mathrm{PO}_{4}$ on anatase $\mathrm{TiO}_{2} .5 \mathrm{~g}$ of $\mathrm{TiO}_{2}$ was stirred in $200 \mathrm{~mL}$ of $1 \mathrm{M} \mathrm{H}_{3} \mathrm{PO}_{4}$ solution. After stirring for $48 \mathrm{~h}$, the collected sample was washed repeatedly with distilled water until phosphate ions were no longer detected. The resulting material was dried overnight at $353 \mathrm{~K}$ and then used as the $\mathrm{H}_{3} \mathrm{PO}_{4} / \mathrm{TiO}_{2}$ catalyst.

\subsection{FT-IR measurement and estimation of the amounts of Lewis acid sites for anatase $\mathrm{TiO}_{2}$ and $\mathrm{H}_{3} \mathrm{PO}_{4} / \mathrm{TiO}_{2}$}

Lewis acid densities on anatase $\mathrm{TiO}_{2}$ and $\mathrm{H}_{3} \mathrm{PO}_{4} / \mathrm{TiO}_{2}$ were estimated for pyridine-adsorbed samples at $298 \mathrm{~K}$ by FT-IR measurements. The samples were pressed into self-supporting disks $(20 \mathrm{~mm}$ diameter, ca. $20 \mathrm{mg}$ ) and placed in an IR cell attached to a closed glass-circulation system $\left(0.38 \mathrm{dm}^{-3}\right)$. The disk was dehydrated by heating at $423 \mathrm{~K}$ for $1 \mathrm{~h}$ under vacuum to remove physisorbed water and was exposed to pyridine vapor at $423 \mathrm{~K}$. The intensities of the bands at $1445 \mathrm{~cm}^{-1}$ (pyridine coordinatively bonded to Lewis acid sites, molecular absorption coefficient: $4.86 \mu \mathrm{mol} \cdot \mathrm{cm}^{-1}$ ) were plotted against the amounts of pyridine adsorbed on the Lewis acid sites of the samples.

In the case of the sample in the presence of saturated water vapor, the disk placed in the IR cell was exposed to saturated $\mathrm{H}_{2} \mathrm{O}$ vapor (20-25 Torr) at room temperature for $60 \mathrm{~min} .4 .2$ layers of $\mathrm{H}_{2} \mathrm{O}$ molecules were adsorbed on the $\mathrm{TiO}_{2}$ and $\mathrm{H}_{3} \mathrm{PO}_{4} / \mathrm{TiO}_{2}$ surfaces, as estimated from water vapor-adsorption-desorption isotherms. Pyridine vapor was then added to the reaction system, and the intensity of the $1445 \mathrm{~cm}^{-1}$ band (pyridine coordinatively bonded to Lewis acid sites) increased with increasing amount of introduced pyridine, reaching a plateau.

\subsection{HMF production from glucose}

THF/aqueous solution (2.0 mL (THF, $1.8 \mathrm{~mL}$; distilled water, $0.2 \mathrm{~mL}$ )) containing D-glucose $(0.02 \mathrm{~g})$ and catalyst $(0.05 \mathrm{~g})$ was heated in a sealed Pyrex tube for $2 \mathrm{~h}$ at $393 \mathrm{~K}$. After filtration, the solutions were analyzed using high performance liquid chromatography (HPLC; LC-2000 plus, Jasco) equipped with refractive index (RI) and photodiode array (PDA) detectors. Aminex ${ }^{\circledR}$ HPH- $87 \mathrm{H}$ column $(300 \mathrm{~mm}$ x $7.8 \mathrm{~mm}$, Bio-Rad Laboratories) with diluted $\mathrm{H}_{2} \mathrm{SO}_{4}$ solution $(5 \mathrm{mM})$ of eluent, $0.5 \mathrm{~mL} \mathrm{~min}{ }^{-1}$ of flow rate, and $308 \mathrm{~K}$ of column temperature was adopted in HPLC analysis.

\section{Results and discussion}

\subsection{Structure of anatase $\mathrm{TiO}_{2}$ and $\mathrm{H}_{3} \mathrm{PO}_{4} / \mathrm{TiO}_{2}$}

Structural information for the anatase $\mathrm{TiO}_{2}$ and $\mathrm{H}_{3} \mathrm{PO}_{4} / \mathrm{TiO}_{2}$ catalysts was obtained by XRD and $\mathrm{N}_{2}$ adsorption analyses. Fig.1 shows XRD patterns and (B) $\mathrm{N}_{2}$ adsorption-desorption isotherms for (a) anatase $\mathrm{TiO}_{2}$ and (b) $\mathrm{H}_{3} \mathrm{PO}_{4} / \mathrm{TiO}_{2}$. Diffraction peaks 

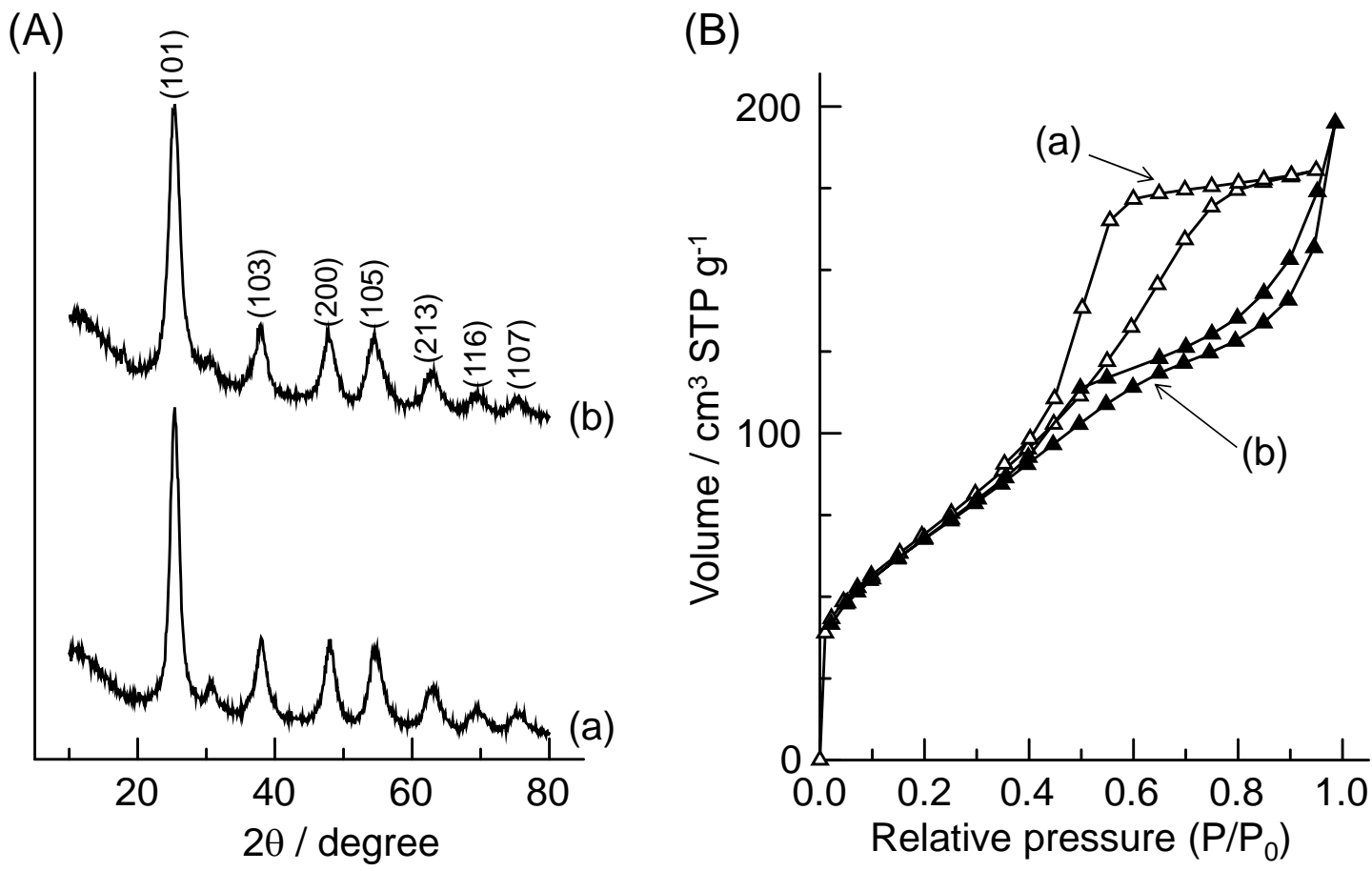

Fig. 1. (A) XRD patterns and (B) $\mathrm{N}_{2}$ adsorption-desorption isotherms for (a) anatase $\mathrm{TiO}_{2}$ and (b) $\mathrm{H}_{3} \mathrm{PO}_{4} / \mathrm{TiO}_{2}$.

due to anatase $\mathrm{TiO}_{2}$ are evident in the XRD patterns for anatase $\mathrm{TiO}_{2}$ and $\mathrm{H}_{3} \mathrm{PO}_{4} / \mathrm{TiO}_{2}$, which indicates that both samples are mainly composed of anatase $\mathrm{TiO}_{2}$. There was no significant difference in the XRD patterns of anatase $\mathrm{TiO}_{2}$ and $\mathrm{H}_{3} \mathrm{PO}_{4} / \mathrm{TiO}_{2}$; therefore, phosphoric acid modification of anatase $\mathrm{TiO}_{2}$ does not change the original anatase $\mathrm{TiO}_{2}$ structure. $\mathrm{N}_{2}$ adsorption-desorption isotherms of the samples are similar to the type-IV pattern, which is typical of mesoporous solids. The Brunauer-Emmett-Teller (BET) surface areas and pore volumes of anatase $\mathrm{TiO}_{2}$ and $\mathrm{H}_{3} \mathrm{PO}_{4} / \mathrm{TiO}_{2}$ were estimated to be $252 \mathrm{~m}^{2} \mathrm{~g}^{-1}$ and $0.31 \mathrm{~mL} \mathrm{~g}^{-1}$, and $266 \mathrm{~m}^{2} \mathrm{~g}^{-1}$ and $0.25 \mathrm{~mL} \mathrm{~g}^{-1}$, respectively. SEM images revealed that the prepared $\mathrm{TiO}_{2}$ sample is composed of $10-20 \mathrm{~nm} \mathrm{TiO} 2$ particles. There was no significant difference in the morphology of $\mathrm{TiO}_{2}$ and $\mathrm{H}_{3} \mathrm{PO}_{4} / \mathrm{TiO}_{2}$. The amount of immobilized phosphate on anatase $\mathrm{TiO}_{2}$ was estimated by inductively coupled plasma-atomic emission spectroscopy (ICP-AES), which revealed that $0.77 \mathrm{mmol}$ of phosphate ions were tightly fixed on $1 \mathrm{~g}$ of $\mathrm{TiO}_{2}$ by ester formation between phosphoric acid and neutral $\mathrm{OH}$ groups.

\subsection{Lewis acid sites on anatase $\mathrm{TiO}_{2}$}

Difference Fourier transform infrared (FT-IR) spectra for pyridine adsorption on dehydrated anatase $\mathrm{TiO}_{2}$ and $\mathrm{H}_{3} \mathrm{PO}_{4} / \mathrm{TiO}_{2}$ are shown in Fig. 2, where pyridine is employed as a basic probe molecule for characterization of the acid sites [11]. Dehydrated $\mathrm{TiO}_{2}$ exhibits several bands (Fig. 2(A)), but there is no signal for pyridinium ions formed on Brønsted acid sites $\left(1540 \mathrm{~cm}^{-1}\right)$, because $\mathrm{TiO}_{2}$ has no Brønsted acid sites. The intensities of the two bands at 1445 and $1440 \mathrm{~cm}^{-1}$, which are assigned to adsorbed pyridine on Lewis acid sites $\left(\mathrm{TiO}_{4}\right)$ and physisorbed pyridine,[12] respectively, increase with the amount of introduced pyridine, and the band intensities due to acid sites reach plateaus at $\mathrm{P}_{\text {pyridine }}>2.8 \times 10^{-2} \mathrm{kPa}$. Fig. $2 \mathrm{~B}$ shows difference FT-IR spectra for pyridine-adsorbed anatase $\mathrm{TiO}_{2}$ and $\mathrm{H}_{3} \mathrm{PO}_{4} / \mathrm{TiO}_{2}$. The samples were treated with saturated pyridine vapor and subsequently evacuated at room temperature 

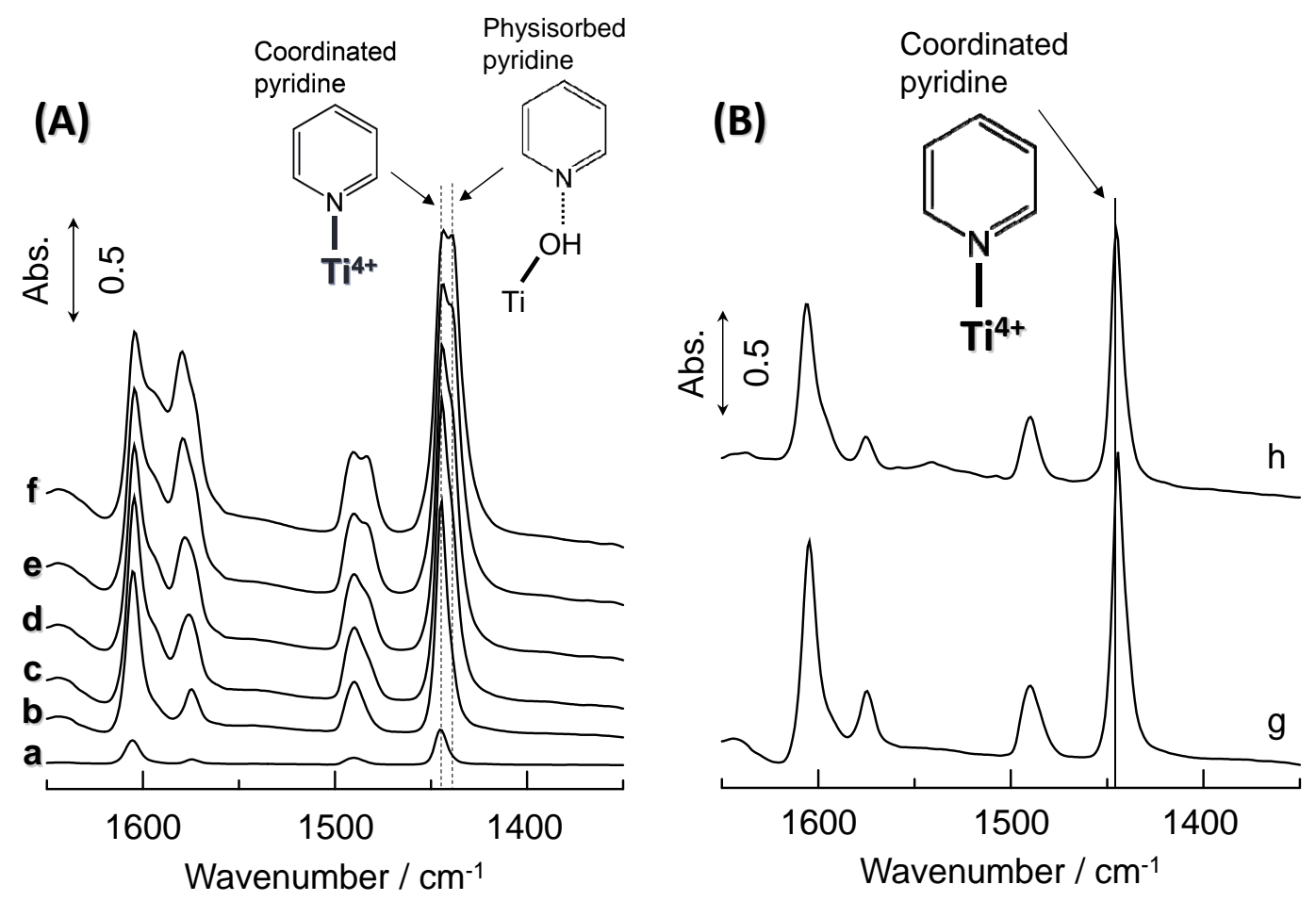

Fig. 2. FT-IR spectra for pyridine-adsorbed dehydrated $\mathrm{TiO}_{2}$ and $\mathrm{H}_{3} \mathrm{PO}_{4} / \mathrm{TiO}_{2}$ at $298 \mathrm{~K}$. (A) Difference FT-IR spectra for dehydrated $\mathrm{TiO}_{2}$. Prior to pyridine adsorption, the $\mathrm{TiO}_{2}$ sample was heated at $473 \mathrm{~K}$ for $1 \mathrm{~h}$ under vacuum to remove physisorbed $\mathrm{H}_{2} \mathrm{O}$. Gas phase pyridine pressure: a, $1.4 \times 10^{-2}$; b, $6.7 \times 10^{-2}$; c, $1.3 \times 10^{-1}$; d, $2.8 \times 10^{-2}$; e, $6.7 \times 10^{-1} ; \mathrm{f}, 1.4 \mathrm{kPa}$. (B) Difference FT-IR spectra for pyridine-adsorbed (g) $\mathrm{TiO}_{2}$ and (h) $\mathrm{H}_{3} \mathrm{PO}_{4} / \mathrm{TiO}_{2}$. Prior to pyridine adsorption, the samples were heated at $473 \mathrm{~K}$ for $1 \mathrm{~h}$ under vacuum to remove physisorbed $\mathrm{H}_{2} \mathrm{O}$. After pyridine adsorption, the samples were evacuated at $298 \mathrm{~K}$ for 60 $\min$.

for $60 \mathrm{~min}$ to remove physisorbed pyridine. Evacuation of the samples results in no change of the band for pyridine adsorbed on Lewis acid sites, whereas the signal for physisorbed pyridine is eliminated. Thus, the maximum intensity of the band at $1445 \mathrm{~cm}^{-1}$ corresponds to the total amount of Lewis acid sites with adsorbed pyridine. The amounts of Lewis acid sites on the dehydrated $\mathrm{TiO}_{2}$ and $\mathrm{H}_{3} \mathrm{PO}_{4} / \mathrm{TiO}_{2}$ samples were estimated to be 0.25 and $0.23 \mathrm{mmol} \mathrm{g}$, respectively, from the maximum band intensities and molecular absorption coefficients at $1445 \mathrm{~cm}^{-1}$. Figs. 3(A) and 3(B) show FT-IR spectra for pyridine-adsorbed $\mathrm{TiO}_{2}$ and $\mathrm{H}_{3} \mathrm{PO}_{4} / \mathrm{TiO}_{2}$, respectively, in the presence of saturated water vapor. Large amounts of physisorbed $\mathrm{H}_{2} \mathrm{O}$ molecules are presented on the $\mathrm{TiO}_{2}$ and $\mathrm{H}_{3} \mathrm{PO}_{4} / \mathrm{TiO}_{2}$ surface prior to pyridine introduction under the experimental conditions; therefore, two large and diffuse bands due to water are observed at 2500-3700 and 1500-1700 $\mathrm{cm}^{-1}$ in Figs. 3(A)(a) and $3(B)(d)$. Even in the case of such water-saturated samples, the band due to pyridine adsorbed on Lewis acid sites $\left(1445 \mathrm{~cm}^{-1}\right)$ appears in Figs. 3(A)(b) and 3(B)(e), in addition to pysisorbed pyridine $\left(1440 \mathrm{~cm}^{-1}\right)$. Although the band for pysisorbed pyridine disappears after evacuation of the samples at room temperature, the signal for Lewis acid sites remains unchanged. The effective Lewis acid densities of $\mathrm{TiO}_{2}$ and $\mathrm{H}_{3} \mathrm{PO}_{4} / \mathrm{TiO}_{2}$ in the presence of saturated water vapor (water-tolerant Lewis acid density) were 0.24 and $0.22 \mathrm{mmol} \mathrm{g}^{-1}$, respectively. This implies that most unsaturated coordination $\mathrm{TiO}_{4}$ tetrahedra still act as Lewis acid sites, even in water, because water does not deactivate these Lewis acid sites, and all unsaturated coordination $\mathrm{TiO}_{4}$ tetrahedra still act as Lewis acid sites even in water and the Lewis acid 

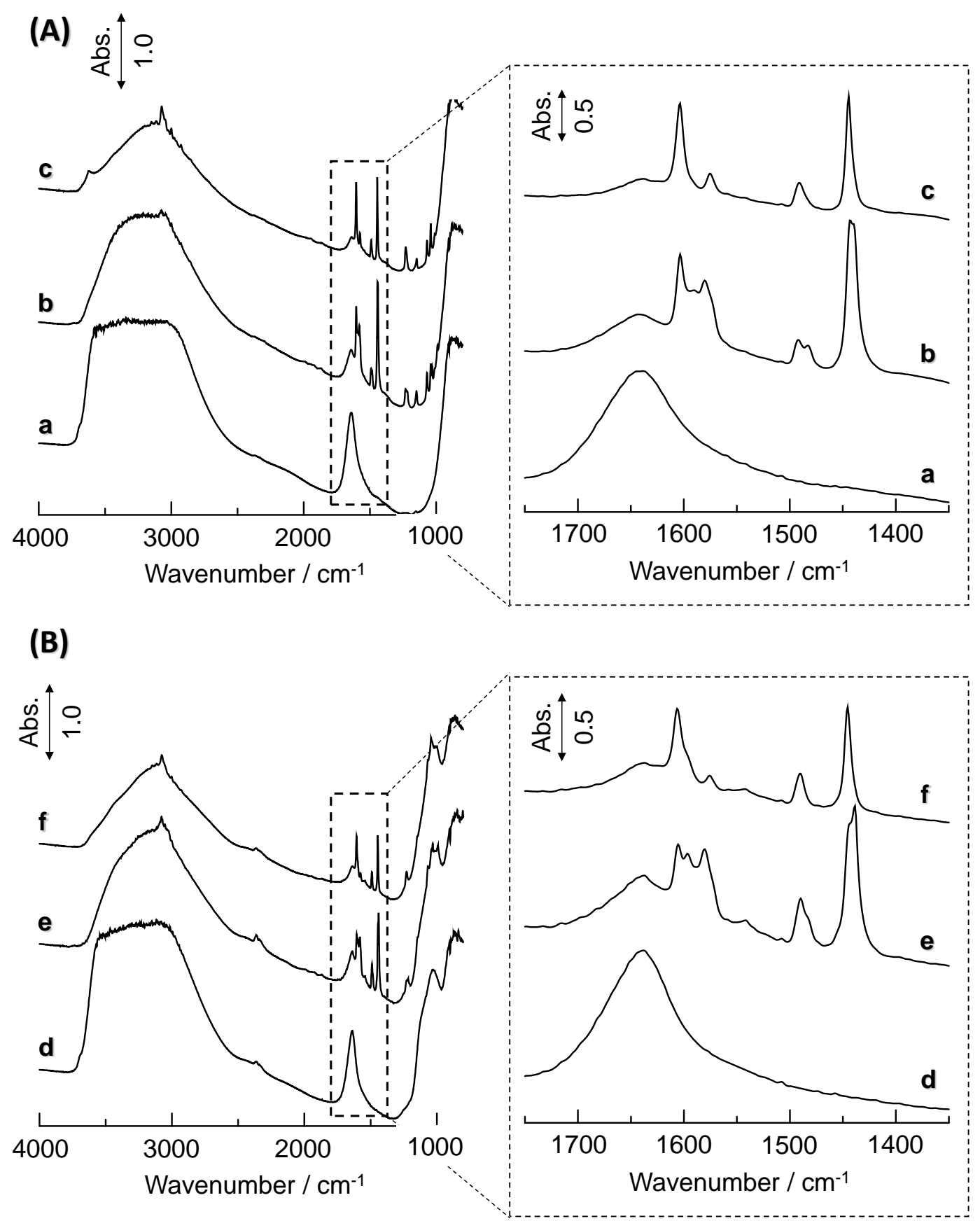

Fig. 3. Difference FT-IR spectra for (A) $\mathrm{TiO}_{2}(\mathrm{~B}) \mathrm{H}_{3} \mathrm{PO}_{4} / \mathrm{TiO}_{2}$ in the presence of saturated $\mathrm{H}_{2} \mathrm{O}$ vapor. a; hydrated $\mathrm{TiO}_{2}$ in saturated $\mathrm{H}_{2} \mathrm{O}$ vapor, $\mathrm{b}$; $\mathrm{TiO}_{2}$ obtained by the introduction of pyridine $(2.7 \mathrm{kPa})$ after $\mathrm{H}_{2} \mathrm{O}$ adsorption under $\mathrm{H}_{2} \mathrm{O}$ vapor, c; $\mathrm{TiO}_{2}$ sample obtained by evacuation (room temperature) for 60 min after (b), d; a hydrated $\mathrm{H}_{3} \mathrm{PO}_{4} / \mathrm{TiO}_{2}$ in saturated $\mathrm{H}_{2} \mathrm{O}$ vapor, e; $\mathrm{H}_{3} \mathrm{PO}_{4} / \mathrm{TiO}_{2}$ obtained by the introduction of pyridine $(2.5 \mathrm{kPa})$ after $\mathrm{H}_{2} \mathrm{O}$ adsorption under $\mathrm{H}_{2} \mathrm{O}$ vapor, $\mathrm{f} ; \mathrm{H}_{3} \mathrm{PO}_{4} / \mathrm{TiO}_{2}$ obtained by evacuation (room temperature) for $60 \mathrm{~min}$ after (e).

sites are not covered with phosphate ions on $\mathrm{H}_{3} \mathrm{PO}_{4} / \mathrm{TiO}_{2}$.

\subsection{Catalytic studies}


Table 1. Catalytic activity for HMF production from glucose over acid catalysts ${ }^{[a]}$

\begin{tabular}{|c|c|c|c|c|c|c|c|c|}
\hline \multirow[t]{2}{*}{ Catalyst } & \multicolumn{2}{|c|}{$\begin{array}{l}\text { Acid density }{ }^{[\mathrm{b}]} \\
/ \mathrm{mmol} \mathrm{g}^{-1}\end{array}$} & \multirow{2}{*}{$\begin{array}{c}\text { Conv. }{ }^{[\mathrm{d}]} \\
(\%)\end{array}$} & \multicolumn{5}{|c|}{$\begin{array}{c}\text { Product yield }{ }^{[\mathrm{e}]} \\
(\%)\end{array}$} \\
\hline & BAS & LAS & & Fru & HMF & FA & LA & Unknown \\
\hline $\mathrm{HCl}$ & 9.9 & 0.0 & 56.2 & 0.0 & 29.4 & 0.0 & 0.0 & 26.9 \\
\hline $\mathrm{H}_{3} \mathrm{PO}_{4}$ & 10.2 & - & 9.2 & 0.0 & 1.2 & 0.0 & 0.0 & 8.0 \\
\hline Amberlyst-15 & 4.8 & - & 69.9 & 2.0 & 12.0 & 0.0 & 24.9 & 31.0 \\
\hline Nafion NR50 & 0.9 & - & 28.7 & 0.0 & 3.1 & 0.0 & 0.0 & 25.6 \\
\hline $\mathrm{Sc}(\mathrm{OTf})_{3}$ & - & 2.0 & $>99.9$ & 1.5 & 13.9 & 0.0 & 0.0 & 84.6 \\
\hline $\mathrm{Yb}(\mathrm{OTf})_{3}$ & - & 1.9 & 89.4 & 0.0 & 10.6 & 0.0 & 0.0 & 78.8 \\
\hline $\mathrm{TiO}_{2}$ & - & $0.24^{[\mathrm{c}]}$ & $>99.9$ & 0.0 & 8.5 & 0.0 & 0.0 & 91.5 \\
\hline $\mathrm{H}_{3} \mathrm{PO}_{4} / \mathrm{TiO}_{2}$ & - & $0.22^{[\mathrm{c}]}$ & 98 & 0.0 & 81.2 & 10.5 & 0.0 & 8.3 \\
\hline
\end{tabular}

[a] Reagents and conditions: distilled water, $0.2 \mathrm{~mL}$; THF, $1.8 \mathrm{~mL}$; D-glucose, $0.02 \mathrm{~g}(0.11 \mathrm{mmol})$; catalyst weight, $0.05 \mathrm{~g}$; temperature, $393 \mathrm{~K}$; time, $2 \mathrm{~h}$. [b] BAS; Brønsted acid sites, LAS; Lewis acid sites. [c] Water tolerant acid sites. [d] Glucose conversion for $2 \mathrm{~h}$. [e] Fru: fructose; FA: formic acid; LA: levulinic acid; Unknown: Undetectable species.

The catalysis of anatase $\mathrm{TiO}_{2}$ was evaluated through the conversion of glucose into HMF in water. Table 1 summarizes results for the conversion of glucose into HMF in an aqueous solution of tetrahydrofuran (THF) at $393 \mathrm{~K}$. The efficiency for HMF production from glucose has been reported to be improved by using THF aqueous solution as a solvent [9]. Homogeneous $\left(\mathrm{HCl}\right.$ and $\left.\mathrm{H}_{3} \mathrm{PO}_{4}\right)$ and heterogeneous Brønsted acids $\left(\mathrm{SO}_{3} \mathrm{H}\right.$-bearing resins: Nafion ${ }^{\circledR N R} 50$ and Amberlyst-15) that were also tested exhibit moderate glucose conversion and HMF yield. Brønsted acids are not effective for the conversion of glucose into HMF at such low reaction temperatures [13], and the HMF produced is decomposed by hydration in water without extraction by appropriate organic solvents $[13,14,15]$. Although rare earth

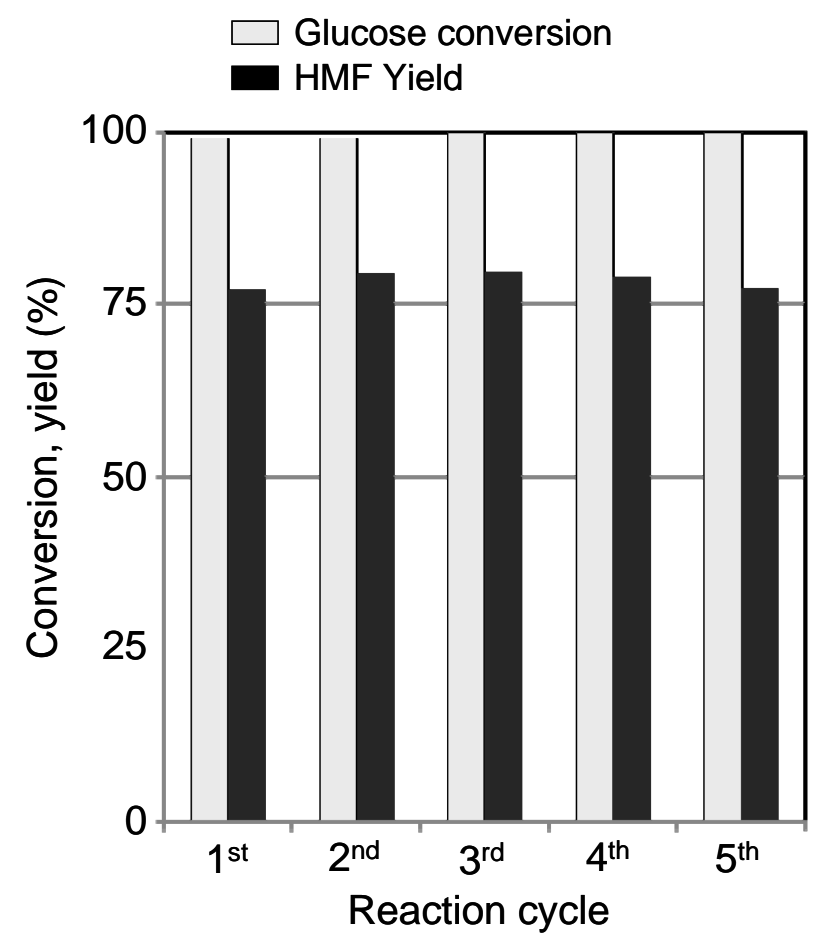

Fig. 4. Catalytic activity of reused $\mathrm{H}_{3} \mathrm{PO}_{4} / \mathrm{TiO}_{2}$ for $\mathrm{HMF}$ production from D-glucose. Reagents and conditions: catalyst, $0.05 \mathrm{~g}$; water: $0.2 \mathrm{~mL}$; THF, $1.8 \mathrm{~mL}$; D-glucose: 0.02 $\mathrm{g}$; temperature, $393 \mathrm{~K}$. 


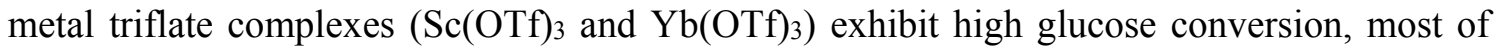
the reacted glucose is converted into unknown species. This can be attributed to the formation of polymerized species $[10,15,16]$. Complex intermolecular side reactions, such as aldol condensation, among reducing saccharides with formyl groups $(-\mathrm{CHO})$ in the presence of acid catalysts result in the formation of complex polymers as unknown species that cannot be detected by HPLC and gas chromatography-mass spectrometry (GC-MS) [10]. Anatase $\mathrm{TiO}_{2}$ also converts most of the glucose into complex by-products, including polymerized species, as with rare earth metal triflate complex catalysts. In contrast to bare $\mathrm{TiO}_{2}, \mathrm{TiO}_{2}$ modified with $\mathrm{H}_{3} \mathrm{PO}_{4}\left(\mathrm{H}_{3} \mathrm{PO}_{4} / \mathrm{TiO}_{2}\right)$, where $-\mathrm{OH}$ groups on $\mathrm{TiO}_{2}$ are esterified into $-\mathrm{O}-\mathrm{PO}(\mathrm{OH})_{2}$ by phosphoric acid, exhibits significant catalytic performance for HMF production; the HMF yield exceeded $80 \%$ within $2 \mathrm{~h}$. There is large difference between levulinic acid and formic acid yield on $\mathrm{H}_{3} \mathrm{PO}_{4} / \mathrm{TiO}_{2}$. One possible explanation is adsorption of the evolved levulinic acid on $\mathrm{H}_{3} \mathrm{PO}_{4} / \mathrm{TiO}_{2}$.[17] After reaction for $2 \mathrm{~h}$ at $393 \mathrm{~K}$, the $\mathrm{H}_{3} \mathrm{PO}_{4} / \mathrm{TiO}_{2}$ particles could be readily separated from the solution by decantation and the recovery of the catalyst exceeded 99\%. The results for reuse experiments of this catalyst are presented in Fig. 4. The recovered catalyst was repeatedly evaluated for HMF production from glucose for $2 \mathrm{~h}$ at $393 \mathrm{~K}$. No decrease in activity was observed, even after 4 reuses of the catalyst sample and the total turnover number reached ca. 40. It was also confirmed that the phosphate ions are not desorbed from the sample during reaction. Therefore, $\mathrm{H}_{3} \mathrm{PO}_{4} / \mathrm{TiO}_{2}$ functions as a stable and highly selective heterogeneous catalyst for simple HMF production from glucose. Fig.5 shows the time courses for the conversion of glucose into $\mathrm{HMF}$ on $\mathrm{H}_{3} \mathrm{PO}_{4} / \mathrm{TiO}_{2}$. Although a small amount of fructose is observed at the initial stage of the reaction (15-30 $\mathrm{min})$, beyond $30 \mathrm{~min}$, fructose cannot be detected. This suggests that produced fructose is immediately consumed for the subsequent reaction and glucose is converted into HMF through isomerization, followed by dehydration even on $\mathrm{H}_{3} \mathrm{PO}_{4} / \mathrm{TiO}_{2}$ as the proposed reaction mechanism shown in Scheme 1. Phosphoric acid itself cannot work as an effective catalyst for the conversion of glucose as shown in Scheme 1: phosphoric acid has much smaller glucose

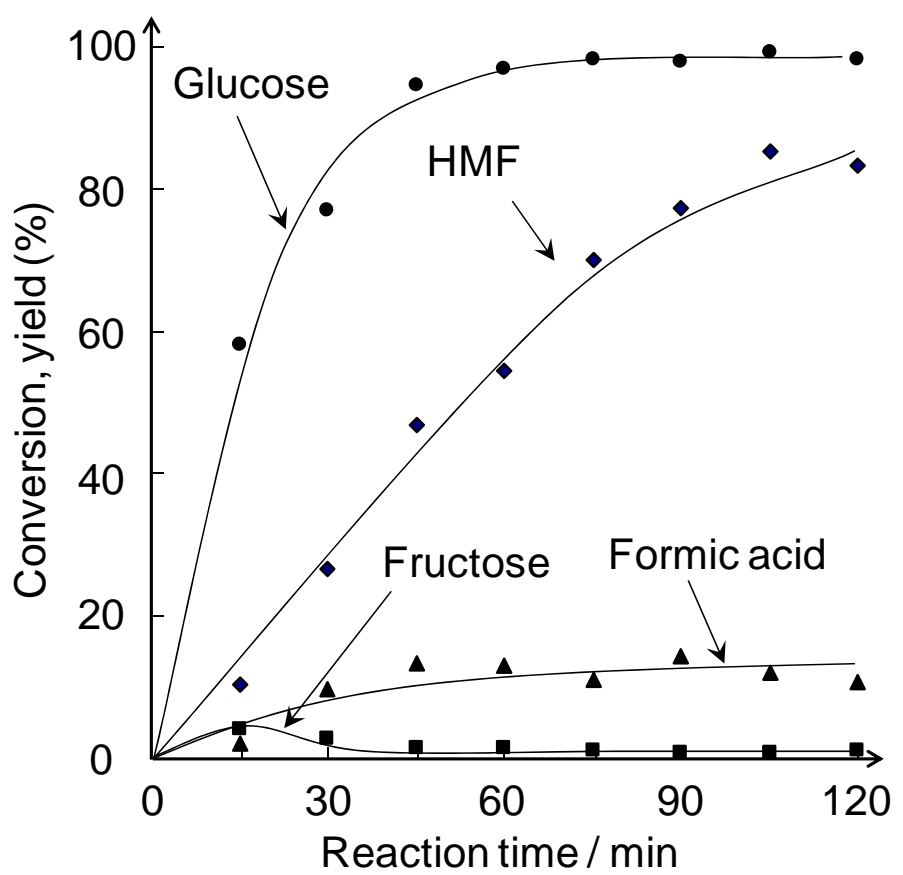

Fig.5. Time courses for the conversion of glucose into $\mathrm{HMF}$ on $\mathrm{H}_{3} \mathrm{PO}_{4} / \mathrm{TiO}_{2}$. Reagents and conditions: catalyst, $0.05 \mathrm{~g}$; water: $0.2 \mathrm{~mL}$; THF, $1.8 \mathrm{~mL}$; D-glucose: $0.02 \mathrm{~g}$; temperature, $393 \mathrm{~K}$. 
conversion and $\mathrm{HMF}$ yield than that bare $\mathrm{TiO}_{2}$ and $\mathrm{H}_{3} \mathrm{PO}_{4} / \mathrm{TiO}_{2}$. Therefore, highly efficient HMF production on $\mathrm{H}_{3} \mathrm{PO}_{4} / \mathrm{TiO}_{2}$ may be due to catalysis of $\mathrm{TiO}_{2}$ Lewis acid sites that interact with reactants even in water. In order to compare the rate of HMF formation from glucose and fructose over $\mathrm{H}_{3} \mathrm{PO}_{4} / \mathrm{TiO}_{2}$, HMF production from fructose was carried out under same reaction condition. THF/aqueous solution $(2.0 \mathrm{~mL}$ (THF, $1.8 \mathrm{~mL}$; distilled water, $0.2 \mathrm{~mL})$ ) containing D-fructose $(0.02 \mathrm{~g})$ and catalyst $(0.05 \mathrm{~g})$ was heated in a sealed Pyrex tube at 393 $\mathrm{K}$ for $30 \mathrm{~min}$. Rate of HMF formation from fructose was estimated to be $0.026 \mathrm{mmol} \mathrm{g}^{-1} \mathrm{~min}^{-1}$ which is slightly larger than that from glucose $\left(0.017 \mathrm{mmol} \mathrm{g}^{-1} \mathrm{~min}^{-1}\right)$. This result also supports that glucose is converted into HMF via fructose. Large-scale experiment was also performed to clarify the recovery of the catalyst. THF/aqueous solution $(2.0 \mathrm{~mL}$ (THF, 1.8 $\mathrm{mL}$; distilled water, $0.2 \mathrm{~mL})$ ) containing D-glucose $(0.2 \mathrm{~g})$ and catalyst $(0.5 \mathrm{~g})$ was heated in a sealed Pyrex tube at $393 \mathrm{~K}$ for $30 \mathrm{~min}$. There was no difference in glucose conversion and HMF yield between small and large-scare experiment, and more than $99 \%$ of catalyst was successfully recovered by simple decantation and filtration.

It should be noted that only water-tolerant Lewis acids on $\mathrm{H}_{3} \mathrm{PO}_{4} / \mathrm{TiO}_{2}$ efficiently catalyze the conversion of glucose into $\mathrm{HMF}$. $\mathrm{Sc}(\mathrm{OTf})_{3}$ catalyzes various reactions as an excellent water-tolerant Lewis acid. However, only a small part of the reacted glucose is converted into HMF on the catalyst. Therefore, Lewis acid catalysis on this complex promotes intermolecular side reactions, including aldol condensation among reducing saccharides, in preference to the isomerization of glucose to fructose and the intramolecular dehydration of fructose. Bare anatase $\mathrm{TiO}_{2}$ also results in significant glucose conversion and low HMF selectivity similar to $\mathrm{Sc}(\mathrm{OTf})_{3}$. As a result, highly efficient $\mathrm{HMF}$ production on $\mathrm{H}_{3} \mathrm{PO}_{4} / \mathrm{TiO}_{2}$ cannot be solely explained by only Lewis acid sites workable in aqueous solution. Phosphoric acid modification on anatase $\mathrm{TiO}_{2}$ causes a significant improvement in HMF production by decreasing side reactions, and the Lewis acid sites are not covered with phosphate ions, as the IR experimental results indicated. This suggests a synergistic effect between Lewis acid sites and phosphate ions essentially changes the acid catalysis on $\mathrm{TiO}_{2}$. The details are currently under investigation.

\section{Conclusion}

In summary, anatase $\mathrm{TiO}_{2}$, an abundant and inexpensive material, has water-tolerant Lewis acid sites. Bare anatase $\mathrm{TiO}_{2}$ cannot function as an efficient heterogeneous catalyst for selective transformation of glucose into $\mathrm{HMF}$, requiring selective isomerization of glucose into fructose and intramolecular dehydration of fructose, because of intermolecular side reactions. On the other hand, $\mathrm{TiO}_{2}$ modified with $\mathrm{H}_{3} \mathrm{PO}_{4}\left(\mathrm{H}_{3} \mathrm{PO}_{4} / \mathrm{TiO}_{2}\right)$, where $-\mathrm{OH}$ groups on $\mathrm{TiO}_{2}$ are esterified into $-\mathrm{O}-\mathrm{PO}(\mathrm{OH})_{2}$ by phosphoric acid, exhibits high $\mathrm{HMF}$ yield (ca. $80 \%$ ) in THF-water mixture $\left(\mathrm{THF} / \mathrm{H}_{2} \mathrm{O}=90 / 10\right)$. Such high $\mathrm{HMF}$ yield can be achieved under diluted glucose solution (ca. $1 \mathrm{wt} \%$ ) and high catalyst/glucose ratio $(50 / 20 \mathrm{wt} \%)$. No decrease

in original activity for subsequent reactions demonstrated that $\mathrm{H}_{3} \mathrm{PO}_{4} / \mathrm{TiO}_{2}$ can function as a stable and reusable heterogeneous catalyst for HMF production.

\section{Acknowledgements}

This work was supported by the Core Research for Evolutional Science and Technology (CREST) and Advanced Low Carbon Technology Research and Development (ALCA) programs of the Japan Science and Technology Agency (JST)

\section{References}


[1] J.N. Chhede, G.W. Huber, J.A. Dumesic, Angew. Chem. Int. Ed. 46 (2007) 7164-7183.

[2] A. Corma, S. Iborra, A. Velty, Chem. Rev. 107(2007) 2411-2502.

[3] H. Zhao, J.E. Holladay, H. Brown, Z.C. Zhang, Science 316 (2007) 1597-1600.

[4] D. Schinzer, Selectiveties in Lewis Acid Promoted Reactions, Kluwer Academic Publishers, Dordrecht, 1989.

[5] P.T. Anastas, M.M. Kirchhoff, Acc. Chem. Res. 35 (2002) 686-694.

[6] S. Kobayashi, I. Hachiya, J. Org. Chem. 59 (1994) 3590-3596.

[7] S. Kobayashi, C. Ogawa, Chem. Eur. J. 12 (2006) 5954-5960.

[8] A. Corma, L.T. Nemeth, M. Renz, S.Valencla, Nature 412 (2001) 423-425.

[9] E. Nikolla, Y. Roman-Leshkov, M. Moliner, M.E. Davis, ACS Catalysis 1 (2011) 408-410.

[10] K. Nakajima, Y. Baba, R. Noma, M. Kitano, S. Hayashi, M. Hara, J. Am. Chem. Soc. 133 (2011) 4224-4227.

[11] R. Buzzoni, G. Ricchiardi, C. Lamberti, A. Zecchina, Langmuir 12 (1996) 930-940.

[12] E. Spano, G. Tabacchi, A. Gamba, E. Fois, J. Phys. Chem. B 110 (2006) 21651-21661.

[13] Y. Román-Leshkov, J. N. Chheda, J. A. Dumesic, Science 312 (2006) 1933-1937.

[14]B. Girisuta, L.P.B.M. Janssen, and H.J. Heeres, Ind. Eng. Chem. Res. 46 (2007) 1696-1708.

[15] M.J. Jr. Antal, W.S.L. Mok, Carbohydr. Res. 199 (1990) 91-109.

[16] H.E. van Dan, A.P.G. Kieboom, H. van Bekkum, Starch-Stärke 38 (1986) 95-101.

[17] We performed adsorption experiment of levulinic acid on $\mathrm{H}_{3} \mathrm{PO}_{4} / \mathrm{TiO}_{2}$. THF/aqueous solution $(2.0 \mathrm{~mL}$ (THF, $1.8 \mathrm{~mL}$; distilled water, $0.2 \mathrm{~mL}))$ containing levulinic acid $(0.11$ $\mathrm{mmol})$ and catalyst $(0.05 \mathrm{~g})$ was stirred at $393 \mathrm{~K}$ for $30 \mathrm{~min}$. The amount of adsorbed levulinic acid was estimated to be ca. $0.10 \mathrm{mmol} \mathrm{g}^{-1}$ which corresponds to ca. $5 \%$ yield. 


\section{Graphical abstract}

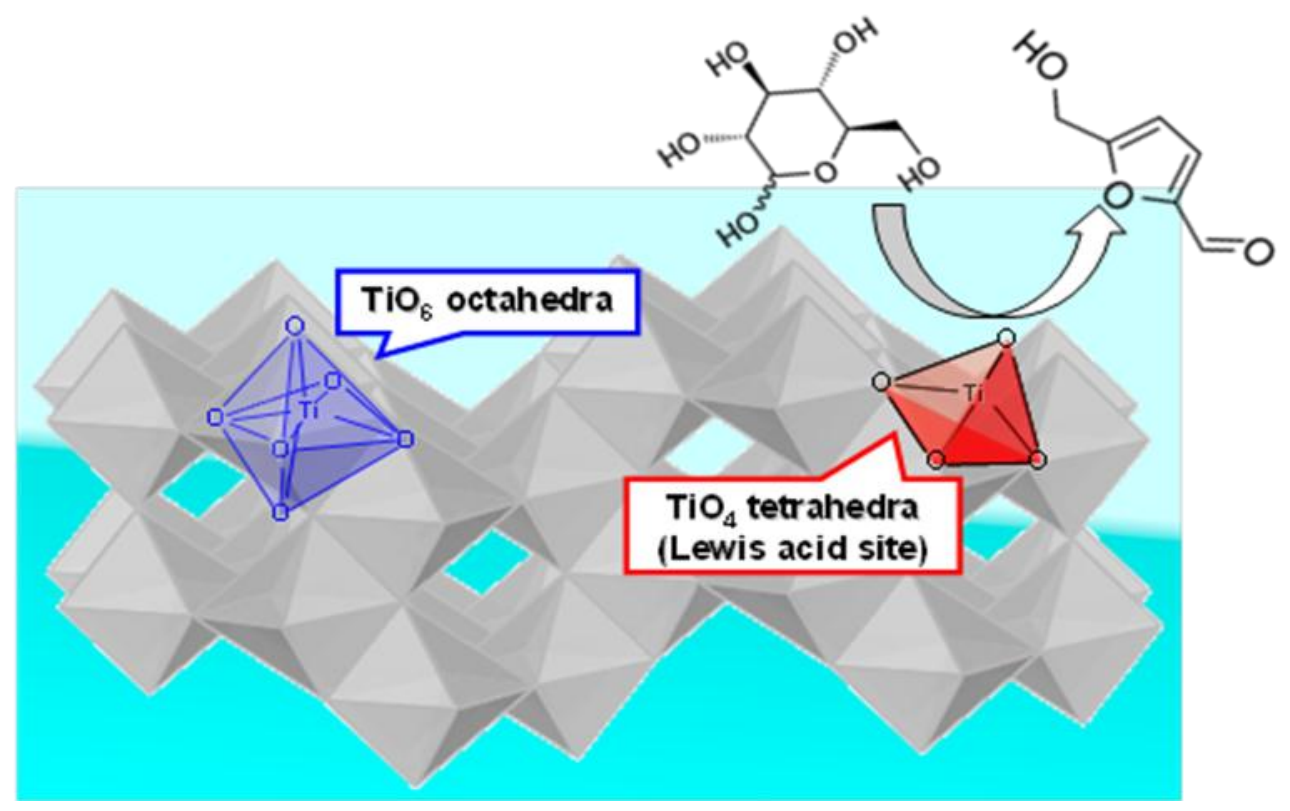

